\title{
KGPS測位位置とレーダ観測位置との比較
}

\author{
山田多津人* ・長澤＼cjkstart明* \\ 高瀬＼cjkstart悟**.平田 法隆**
}

\section{Precision of Radar Positions Compared with the KGPS Positions}

\author{
Tatsuto YAMADA, Akira NAGASAWA, \\ Satoru TAKASE and Noritaka HIRATA
}

\begin{abstract}
Errors of a vessel's position by radar observations has not been determined sufficiently, because we do not have a high accuracy method to fix their positions at sea. But recently, a vessel's position can be obtained with high accuracy by using kinematic GPS (KGPS) in addition to a land survey in various fields.

We carried out the experiments to compare radar positions with KGPS positions in the KURUSHIMA strait using the training vessel "KOJIMA" with the KGPS receiver on board. The positions of KOJIMA obtained by a radar were accepted from the radar sight which belongs to HONSHU-SHIKOKU Bridge Authority. After KGPS positions were exchanged to the plane coordinates, the difference between the two positions were examined and the results were as follows.

1. The radar positioning accuracy were $26.4 \mathrm{~m}$ in length and $7.7 \mathrm{~m}$ in width as $1 \sigma$.

2. The errors in width showed the normal distribution.

3. The vessel's course and speed estimated by radar observations often indicated sharp fluctuations.

4. The bearing errors of radar became greater at shorter distance.
\end{abstract}

\section{1.はじめに}

GPSによる測位精度を向上させる有効な方法としてDGPSがあり、特に、搬送波位相の測定により数 $\mathrm{cm}$ の精度で移動体の位置を求める手法としてキネマティックGPS（以下、「KGPS」という）がある。KGPS は、良好な測位精度及び実時間性等の特性から測量以外の様々な分野での応用利用が検討されている。一 方、海上交通実態調査等で実施されるレーダ観測により取得された船舶の位置データは、様々な利用目的 を持った基礎資料となっているが、比較対象となる船舶の高精度な位置情報が得られなかったこと等から、 レーダ観測位置の定量的な精度評価は厳密にはなされていないと思われる。そこで、海上保安大学校練習 船「こじま」（総トン数 3,090 トン、全長 $115 \mathrm{~m}$ 、最大幅 $14 \mathrm{~m} 、 2$ 軸 2 舵）にKGPS受信機を搭載し、来島海 峡通峡時の測位を行いここの測位位置と陸上のレーダ観測から得られた「こじま」の位置とを比較するこ とで、レーダ観測位置の精度について検討したところ、幾つかの知見を得たので報告する。

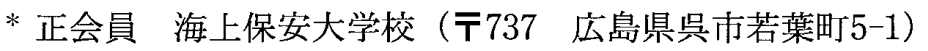

**正会員 広島大学工学部（宁739 広島県東広島市鏡山1-4-1）
} 


\section{2. 解析方法}

\section{1 レーダ 観測位置とKGPS測位位置}

KGPSは、測量目的に利用されることが多い測位システムであり、観測エリア近傍の固定点に基準局を置 き、GPS衛星からの搬送波位相を計測して求めた衛星までの距離情報に、基準局の距離情報から得た誤差 成分を補正することにより、数cmの精度でWGS-84座標系上の位置を出力することが可能である。今回の 測定では、基準局を馬島の来島第 2 大橋 $6 \mathrm{P}$ 橋脚上に設置した。使用した機器は、トリンブル社製の 4000 $\mathrm{SSi}$ 受信機及び特定小電力による補正情報の送信モデルである。「こじま」側にも基準局と同じ型式の受信 機を、船首、船尾及び上部船橋左右舷に計 4 台設置した。この内、解析に利用したデータは、基準局の位 置情報から補正した船首及び船尾の位置データ（1 秒ごとに記録されている）である。

レーダ観測位置は本州四国連絡橋公団今治情報管理室（以下、「情報管理室」という）から提供を受けた。 情報管理室は、本州四国連絡橋「尾道一今治ルート」内の来島海峡において、船舶の航行安全と工事の円 滑な推進を図るため、様々な情報収集、伝達及び調整を行っており、当該業務の一環として、来島海岪付 近の船舶の動向を、レーダ装置により24時間連続した観測を行っている。

レーダ送受信機は、津島及び湊町の 2 力所に設置されており、ここで得られた映像情報は、専用回線に より情報管理室内のマルチレーダ処理装置（株）日本無線製）と呼ばれる、レーダ映像の合成装置により処 理され、管制卓のCRT上に表示される。あらかじめ定められたエリア内に船舶が入ると、ARPAと同様の 処理形態により自動捕捉・追尾され、当該船舶の座標值、速力及び針路が一定な時間間隔でフロッピーデ イスクに記録される。この座標值は、情報管理室を原点、北を十Y、東十Xをする平面座標でメートル単 位の表記となっている。図 1 に実験海域の概要を、また、表に座標原点位置等の概要を示す。

\section{2 座標変換}

レーダ観測位置は情報管理室を原点とする平面座標で表されているため、KGPS測位位置を当該平面座標 に変換する必要がある。

まず、WGS-84測地座標系の緯度 $(\phi)$ 、経度 $(\lambda)$ 、高さ $(h)$ として得られたKGPS測位位置を直交座 標位置 $(x, y, z)$ に、次式にて変換する。

$$
\begin{aligned}
& x=(N+h) \times \cos (\phi) \times \cos (\lambda) \\
& y=(N+h) \times \cos (\phi) \times \sin (\lambda) \\
& z=\left\{N \times\left(1-e^{2}\right)+h\right\} \times \sin (\phi)
\end{aligned}
$$

但し、 $x, y, z$ : 観測点のWGS-84座標系での直交座標位置

$\phi, \lambda, \quad h$ : 観測点のWGS-84座標系での緯度、経度、高さ

$e: \mathrm{WGS}-84$ 座標系の離心率

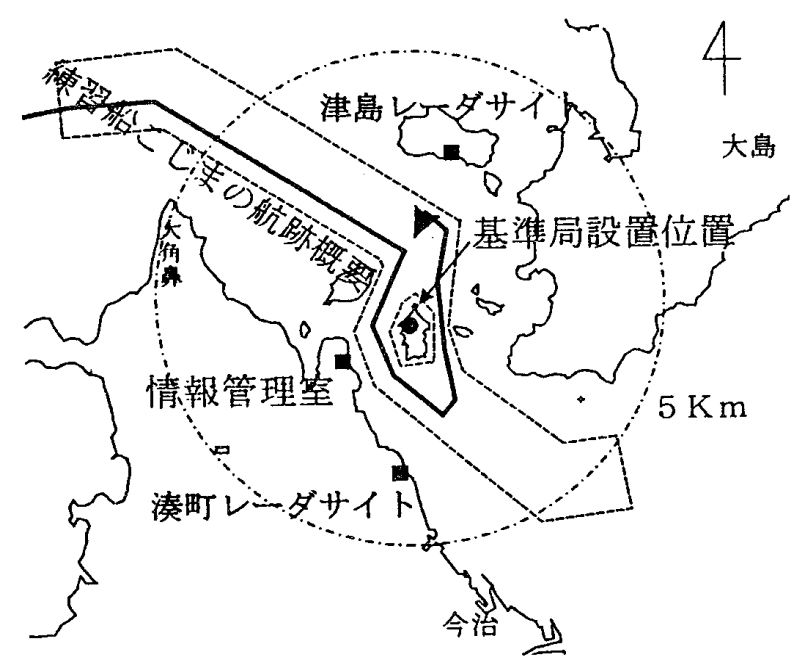

\begin{tabular}{|c|c|}
\hline $\begin{array}{l}\text { 情報管理室原点位畨 } \\
\text { (日本測地系) }\end{array}$ & $\begin{array}{r}34^{\circ}-06^{\prime} 26^{\prime \prime} \mathrm{N} \\
132^{\circ}-58^{\prime} 56^{\prime \prime} \mathrm{E}\end{array}$ \\
\hline $\begin{array}{l}\text { 津島レーダサイト位置 } \\
\text { (日本測地系) }\end{array}$ & $\begin{array}{r}34^{\circ}-06^{\prime} 47^{\prime \prime N} \\
133^{\circ}-00^{\prime} 05^{\prime \prime} \mathrm{E}\end{array}$ \\
\hline $\begin{array}{l}\text { 湊町レーダサイト位置 } \\
\text { (日本測地系) }\end{array}$ & $\begin{array}{r}34^{\circ}-05^{\prime} 31^{\prime \prime N} \\
132^{\circ}-59^{\prime} 28^{\prime \prime} \mathrm{E}\end{array}$ \\
\hline $\begin{array}{l}\text { 馬島基準局位置 } \\
\text { (WGS-84 測地系) }\end{array}$ & $\begin{array}{r}34^{\circ}-14^{\prime} 02^{\prime \prime} .71277 \mathrm{~N} \\
132^{\circ}-23^{\prime} 59^{\prime \prime} .60081 \mathrm{E}\end{array}$ \\
\hline (レーダの主要目) & \\
\hline 周波数 & $9740 \mathrm{MHz}$ \\
\hline パルス幅 & $0.1 \mu \mathrm{s}$ \\
\hline 水平ビ二厶幅 & $0.8^{\circ}$ \\
\hline 送信出力 & $15 \mathrm{~kW}$ \\
\hline GPS 受信機 & Trimble $400 \mathrm{SSi}$ \\
\hline
\end{tabular}

図 1 実験海域の概要 表＼cjkstart座標原点位置等の概要 


$$
N=a /\left\{1-e^{2} \times \sin ^{2}(\phi)\right\}^{1 / 2} \quad a: \text { WGS-84座標系の長半径 }
$$

次に、WGS-84直交座標位置 $(x, y, z)$ を、日本測地系の直交座標位置 $(X, Y, Z)$ に変換する。 $\Delta X 、 \Delta Y 、 \Delta Z$ は平行移動量、 $\theta 、 \xi 、 \omega$ は回転量、 $S$ をケールファクターとすると、

$$
\left(\begin{array}{c}
X \\
Y \\
Z
\end{array}\right)=(1+S) \times\left(\begin{array}{ccc}
1 & -\theta & \omega \\
\theta & 1 & -\xi \\
-\omega & \xi & 1
\end{array}\right) \times\left(\begin{array}{l}
x \\
y \\
z
\end{array}\right)+\left(\begin{array}{c}
\Delta X \\
\Delta Y \\
\Delta Z
\end{array}\right)
$$

となる ${ }^{(1)}$ 。

更に、この日本測地系における直交座標位置 $(X, Y, Z)$ を緯度 $\left(\phi_{1}\right)$ 、経度 $\left(\lambda_{1}\right)$ 、高さ $\left(h_{1}\right)$ に次 式にて変換する。

$$
\begin{aligned}
\phi_{1} & =\tan ^{-1}\left\{\frac{Z+e_{2}{ }^{2} \times \sin ^{3}(\alpha)}{p-e_{1}{ }^{2} \times \cos ^{3}(\alpha)}\right\} \\
\lambda_{1} & =\tan ^{-1}(Y / X) \\
h_{1} & =\left\{P / \cos \left(\phi_{1}\right)\right\}-N_{1} \\
& p=\left(X^{2}+Y^{2}\right)^{1 / 2} \quad \alpha=\tan ^{-1}\left(\frac{Z \times a_{t}}{p \times b t}\right)
\end{aligned}
$$

但し、

$$
\begin{gathered}
e_{1}^{2}=\left(a t^{2}-b t^{2}\right) / a_{t}^{2} \quad e_{2}^{2}=\left(a t^{2}-b t^{2}\right) / b_{t}^{2} \\
N_{1}=a_{t} /\left\{1-e_{1}^{2} \times \sin ^{2}\left(\phi_{1}\right)\right\}^{1 / 2} \\
a_{t}: \text { ベッセル回転楕円体の長半径 } \quad b_{t}: \text { ベッセル回転棈円体の短半径 }
\end{gathered}
$$

最後に、(3)式により求めた緯度（ $\phi_{1} ）$ ・経度 $\left(\lambda_{1}\right)$ を、情報管理室の位置（ $\phi_{0} 、 \lambda_{0} ）$ を原点とする、YX 平面座標 $\left(X_{1} 、 Y_{1}\right)$ に次式にて変換する。

$$
\begin{aligned}
& X_{1}=\frac{a_{1} \times \cos \left(\phi_{1}\right)}{\left\{1-e_{1}{ }^{2} \times \sin ^{2}\left(\phi_{1}\right)\right\}^{1 / 2}} \times\left(\lambda_{1}-\lambda_{0}\right) \\
& Y_{1}=\frac{a_{1} \times\left(1-e_{1}{ }^{2}\right)}{\left\{1-e_{1}{ }^{2} \times \sin ^{2}\left(\phi_{1}\right)\right\}^{3 / 2}} \times\left(\phi_{1}-\phi_{0}\right)
\end{aligned}
$$

以上により、KGPS測位位置を情報管理室位置を原点とする平面座標に変換し、レーダ観測位置との比較解 析が可能となる。

\section{3 誤差要因}

KGPS測位位置を真位置とした時、レーダ観測位置との差がレーダ観測による測定誤差となり、その誤差 要因には以下の事項が考えられる。

(1)レーダ観測データに記録される時刻とKGPS測位時刻との差による誤差（時刻差に起因する誤差）

各測定値は、レーダ観測においては約30秒間隔で、KGPS測位では 1 秒間隔で記録される。比較する両方 の時刻が整合しておらず、差がある場合には、「こじま」の速度べクトルに応じた測定誤差となって現れる。 当該誤差の影響を最小にするためには、レーダ観測記録時刻に最も近いKGPS測位時刻を決定する必要があ る。

(2) 情報管理室位置及び座標変換に係わる誤差（固定䛊差）

情報管理室の位置は、緯度・経度とも秒の単位まで求められているが、当該緯度・経度における 1 秒の 距離は、緯度方向で $30.8 \mathrm{~m}$ 、経度方向で $25.7 \mathrm{~m}$ となっている。このため、座標原点位置の緯度・経度の秒 の単位の丸めの䛊差が固定誤差となって残る。

また、(2)式において実際の計算では、スケールファクター及び回転量を 0 とし、平行移動量の值を、

$\Delta X=146.43(\mathrm{~m}) \quad \Delta Y=-507.89(\mathrm{~m}) \quad \Delta Z=-681.46(\mathrm{~m})$ (筑波のVLBI座標值との差 ${ }^{(2)}$ ) とし た。本来のGPS測量によれば、観測地域の周辺や内部に国家基準点を 3 点以上拘束して、局所的に網平均 をかけ、スケールファクター等を考慮した局所的な座標変換を行うことで、数 $\mathrm{cm}$ 程度の精度で両座標值を 整合することが可能となるが(1)、今回は、測定上の制約からこの手法は採用できなかった。しかし、比較す るレーダ 観測位置は高さの情報を持たない 2 次元座標であること、また、対象とする海域は数km四方の範 
囲であることから、同海域内に括いては一定の座標変換誤差（固定誤差）として取扱える。

(3) レーダ測定誤差

情報管理室のレーダシステムにおける船舶の位置検出アルゴリズムの概要は以下の通りであった。

（a）船舶映像の方位は、一定の信号強度（しきい值）以上を示す映像信号のビーム方向の広がりの平均 值とする。

（b）船船映像までの距離は、一定の信号強度（しきい值）以上を示す映像信号のスイープ方向の広がり の平均值から、ある重み付けにより観測位置に近づくよう補正した距離゙とする。

(c) 船舶映像の方位と距離加ら X、Y座標值を計算する。

以上の誤差要因をまとめ、以下の通り表す。

$$
\begin{aligned}
& e_{X}=f_{X}(v, C o, t)+d X+g_{X}(R, \beta) \\
& e_{Y}=f_{Y}(v, C o, t)+d Y+g_{Y}(R, \beta)
\end{aligned}
$$

$$
e_{X}, e_{Y}: X 、 Y \text { 方向誤差成分 } f_{X}, f_{Y}: \text { 時刻差に起因する誤差 }
$$

但し、 $d X, d Y$ : 固定誤差 $\quad g X, g_{Y}:$ レーダ測定誤差

$$
v: \text { 速力 } C o \text { : 針路 } t: \text { 時刻差 } R: \text { 測定距離 } \beta: \text { 測定方位 }
$$

X、Y方向誤差成分 (KGPS測位位置とレーダ観測位置の差) から時刻差に起因する誤差及び固定誤差を 除去後、レーダ測定誤差について解析を行った。

\section{3. 解析結果}

\section{1 時刻差に起因する誤差及び} 固定誤差

図 2 に、レーダ観測位置とKGPS 測位位置による航跡を示す。KGPS 測位位置は、船首及び船尾の測位 位置を2.2に示した方法により変換 し、その平均值（船体中央位置） をプロットした。同図中、の印が レーダ観測位置、印がKGPS測定 位置である。比較する両方の位置 に時間差があるため、「こじま」の 速度ベクトルに対応した誤差及び 固定䛊差の発生が見て取れる。

2.3の(5)式に示す時刻差に起因す る誤差（ $\left.f_{X}, f_{Y}\right)$ を確定するため に、レーダ観測時刻と同時刻を示 すKGPS測位位置とのX及びY方向 誤差と、その時刻におけるX及び Y方向速度成分との相関関係を調 べた。図 3 にその散布図を示す。 グラフ中の直線は最小二乗法によ

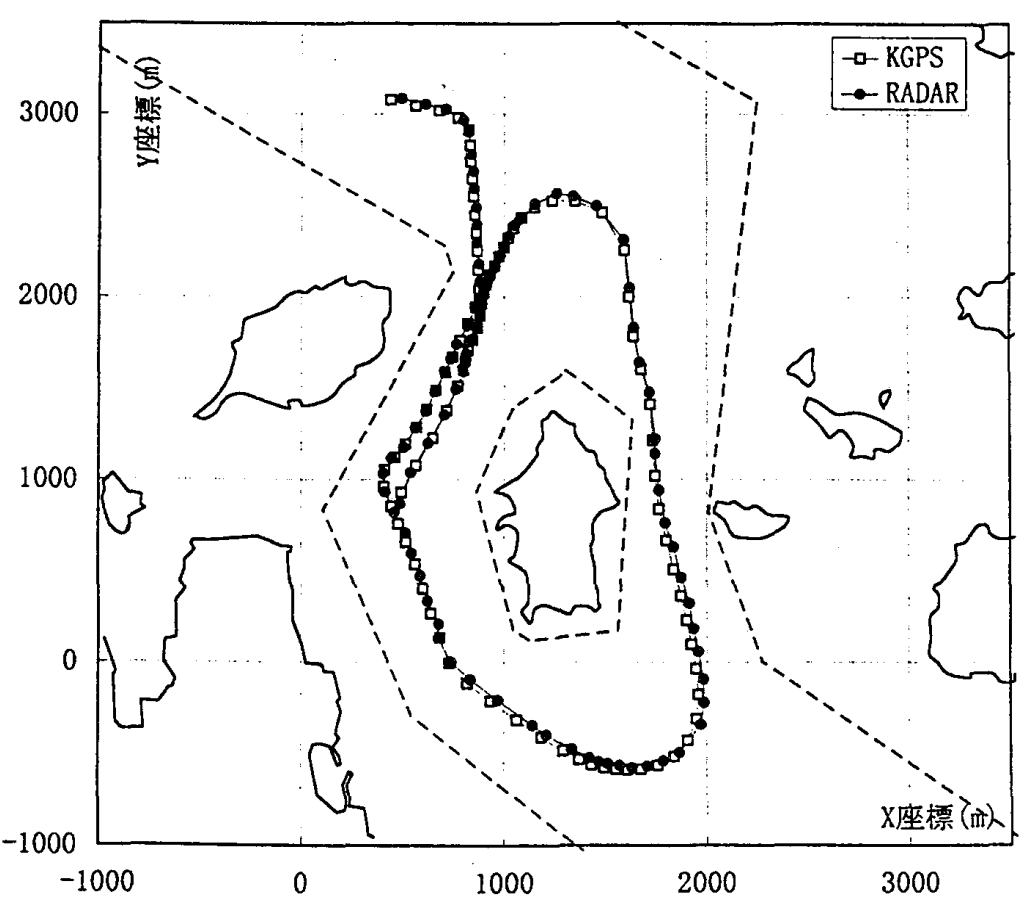

図 2 レーダ観測位置とKGPS測位位置による航跡 り求めた回㷌直線（相関係数0.8229）で、縦軸に誤差量、横軸に速力を取っているため、当該直線の傾き が時刻差であると考えられる。情報管理室におけるレーダ観測時刻の、観測日当日のJSTからの時刻差は明 確な記録がなく不明であったが、観測者からの聞き取り調查によると、「JSTとの時刻差を 1 日 $1 \sim 2$ 回程

*(b ) における「ある重み付けにより観測位置に近づくよう補正した距離」とは、メーカーのノウハウの部分にも関わり、ブラ ックボックス的な扱いをせざるをえないが、一般的なレーダの方位・距離の測定方法に良くあったアルゴリズムで構成されてい ると考えられる。しかし、当該船舶までのレーダ方位及び距離は、レーダ映像信号の状態等により変化するため、レーダ観測位 置には誤差を生ずることになる。 
度確認し、JSTからのずれが最大で数秒を越えな いよう時刻整合を行う。」という、情報管理室の運 用主旨からして十分な精度での管理形態であっ た。一方、KGPS測位時刻は、GPS時により記録 される。GPS時は観測日においてはUTCより11秒 進んでいることから、秒の単位ではJSTからも11 秒進んでいる。同図中の回帰直線の傾き「10.1」 は、以上の事項から判断して妥当な数值と考えら れる。このことにより、KGPSの時刻を秒の単位で 10秒ずらした測位位置とレーダ観測位置を比較す ることにより、時刻差に起因する誤差は除去でき るものとして以後の解析を行った。

固定誤差 $(d X, d Y)$ は、KGPS測位位置とレ 一ダ観測位置の美の平均值と考えられる。図 4 に XY方向誤差のばらつきを示す。平均値は、X方向 (経度方向) $+9.1 \mathrm{~m} 、 \mathrm{Y}$ 方向（緯度方向）+14.1 $\mathrm{m}$ 之なり、座標原点位置の丸めの誤差の大きさか ら判断しても妥当な值であることが推察できた。

\section{2 レーダ測定誤差}

\section{$3.2 .1 \mathrm{XY}$ 平面座標值として}

船首及び船尾のKGPS位置より「こじま」の船首 方位を求め、「こじま」の船首方向を+Y軸に、右 舷正横方向を+X軸とした場合の各誤差量の分布 状況を図 5 に示す。同図におていはアスペクト角 (A)を $0^{\circ} \sim 90^{\circ}$ の範囲で $15^{\circ}$ ごとに規格化し各記 号で表している。船首尾方向誤差の標準偏差は $26.4 \mathrm{~m}$ 、正横方向誤差の標準偏差は $7.7 \mathrm{~m}$ となっ た。船首尾方向誤差及び正横方向誤差それぞれに つきリリフォースの正規性検定を行った結果、正 横方向誤差についてはD統計值 $=0.05858$ でリリ フォースの有意確率 0.2 以上となり、正規分布に従 わないとする仮説が棄却できないことより、ほぼ 正規分布を示すことが確認できた。一方、船首尾 方向誤差は同様の検定により、D統計值 $=0.09676$ でリリフォースの有意確率 0.05 以下となり正規分 布に従わないという結果になった。

\section{2 .2 極座標値として}

式(5)に示すように、レーダ測定誤差は方位誤差 と距離誤差に分けられる。KGPS測位位置とレーダ 観測位置における座標原点からの方位・距離をそ れぞれ計算し、それらの差を方位誤差及び距離誤 差として解析を行った。これは、レーダ観測位置 を極座標値として扱う場合に相当する。

座標原点からの距離と距離誤差及び方位誤差の 関係を図 6 亿示す。同図中、横軸に座標原点から の距離を、右縦軸に方位誤差を- $4^{\circ} \sim+4$ 度の範 囲で、左縦軸に距離誤差を $-80 \mathrm{~m} \sim+80 \mathrm{~m}$ の範囲

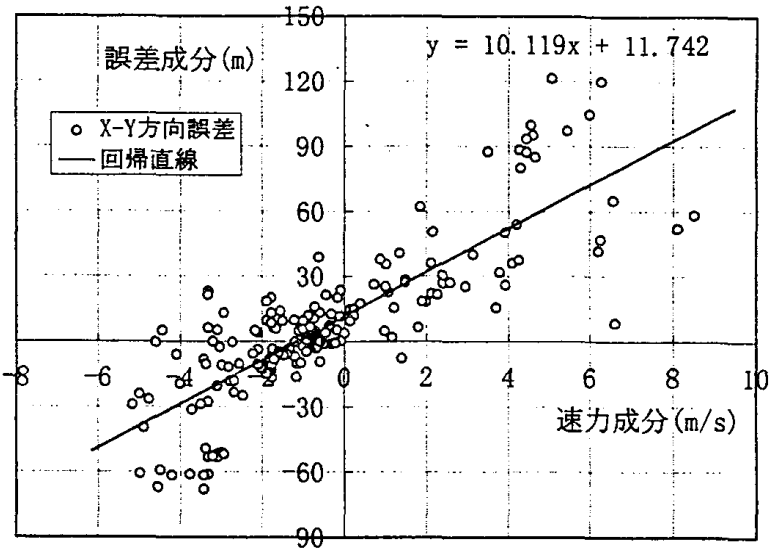

図 3 誤差成分と速力成分の関係

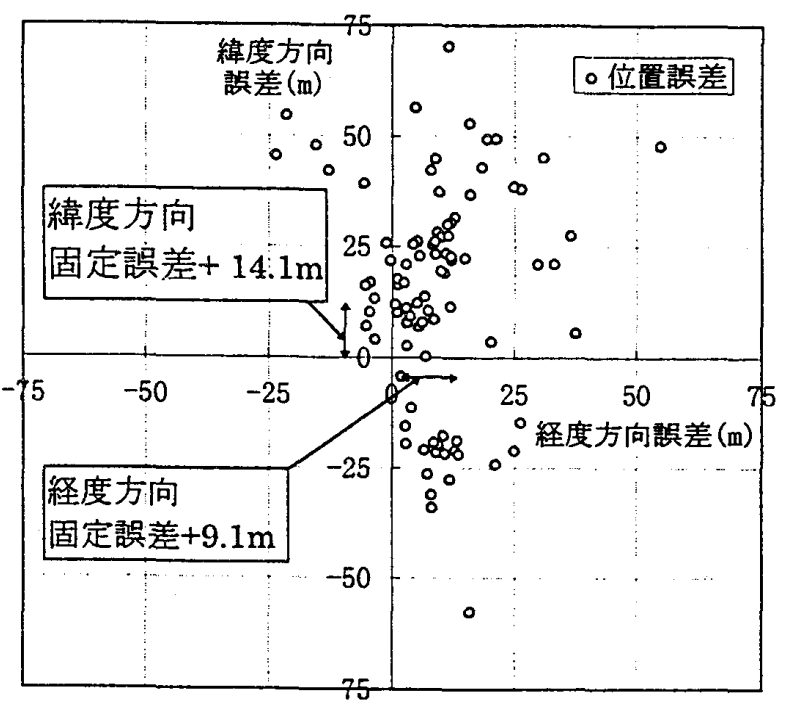

図 4 誤差の分布状況

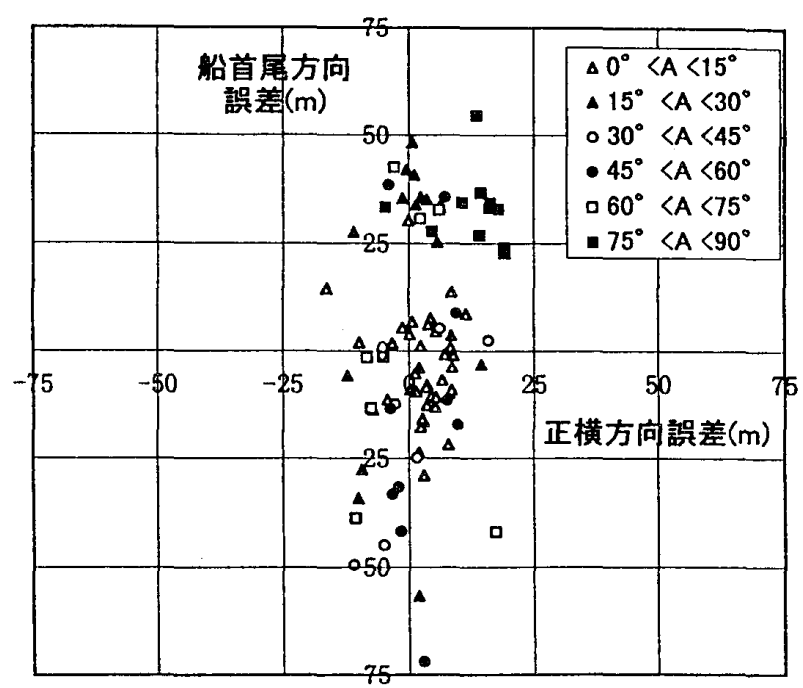

図 5 船首尾・正横方向誤差の分布状況 
で取り、○印を方位䛊差、国印を距離誤差として 表している。

今回の測定海域程度の広さ及びレーダ信号の処 理方法では、座標原点からの距離の变化による距 離誤差の発生状況には特徵的な傾向は特に見られ ず、また、リリフォースの正規性検定により距離 誤差はほぼ正規分布していることが分かった。一 方、同図から方位鿁差は、距離が近い程、特に1,000 $\mathrm{m} よ り も$ 近距離になると大きな誤差が発生する傾 向がうかがえ、同様の正規性の検定から、正規分 布に従わないことが分かった。

\section{4. 考察}

3. で得られた解析結果から、海上交通の評価

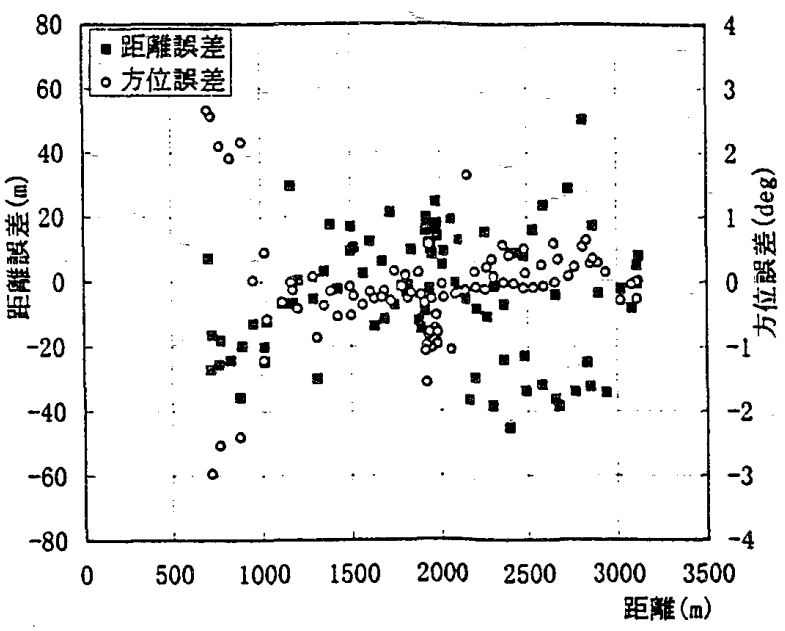

図 6 距離誤差と方位誤差の状沉 に利用される諸要素に、レーダ測定誤差が及ぼす影響等について以下に考察する。

\section{1 ゲート通過隻数}

ゲート通過隻数の集計は、航路帯などの船舶交通流の状況把握に用いられるものであるが、ゲート幅の 設定は、海域の状況や解析目的によって、解析者が任意に選ぶことが多い。3.2で解析した誤差の内、正横 方向誤差の分布はダート通過隻数の集計に影響を及ぼす要素となるので、その統計的性質を利用し、ゲー ト幅による通過隻数の積算カウントの誤り発生の確率を試算した。図 7 にその考え方を示す。ゲート幅を $D$ とし、グート中のレーダ観测による船舶通過位置を $\mu$ とすると、正横方向誤差の正規性から当該船舶の 真のゲート通過位置の確率 $P_{1}(x)$ は、以下の式で表せる。

$$
P_{1}(x)=\frac{1}{\sqrt{2 \pi \sigma}} e^{\frac{-(x-\mu)^{2}}{2 \sigma^{2}}}
$$

(6) 但し、 $\sigma$ ：標準偏差とする。

この場合、ゲート外を通過する確率は、同図中の黒色で塗りつぶした領域に相当し、ここではこの確率を

「ダート誤り確率」と呼ぶこととする。今、ゲート内を通過する $N$ 隻の船舶は当該ゲート内は一様分布す ると仮定した場合、平均的なゲート誤り確率は次式で計算される。

$p(x)=\frac{1}{N} \times \sum_{i=1}^{N}\left\{\int_{-\infty}^{0} \frac{1}{\sqrt{2 \pi \sigma}} e^{\frac{-(x-\mu)^{2}}{2 \sigma^{2}}} d x+\int_{D}^{+\infty} \frac{1}{\sqrt{2 \pi \sigma}} e^{\frac{-(x-\mu)^{2}}{2 \sigma^{2}}} d x\right\}$

但し、 $\mu=\frac{D}{N} \times i(i=1,2, \cdots N)$
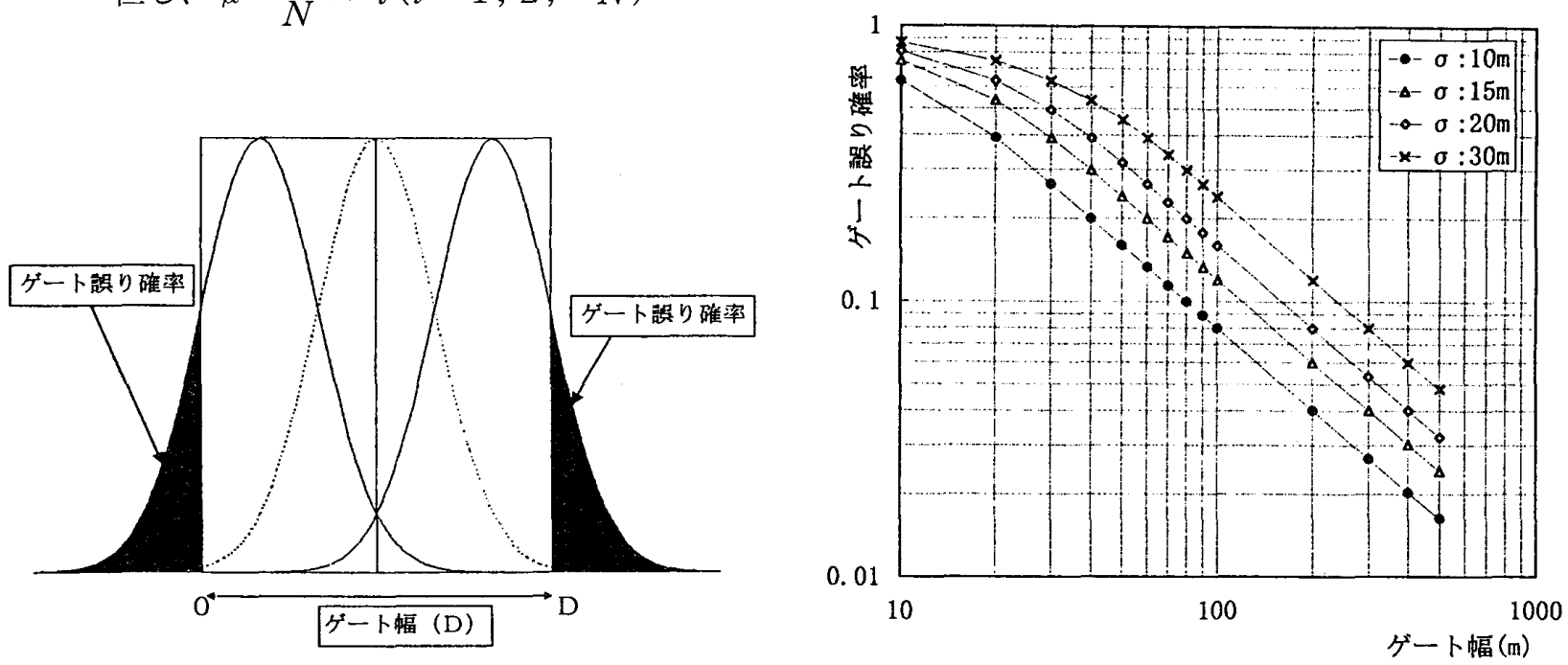

図 7 ゲート誤り確率の考え方

図 8 ゲート鿁り確率の試算結果 
図 8 に、 $N=100$ 隻、 $\sigma=10 \mathrm{~m} \sim 30 \mathrm{~m}$ とした場合に ついて、ダート幅 $(D)$ を $10 \mathrm{~m} \sim 500 \mathrm{~m}$ の間で変化 させた時のゲート䛊り確率 $(p(x))$ の試算結果を 示す。この図から、例えば、今回の正横方向誤差 の大きさから、。を $10 \mathrm{~m}$ と見積もる時、ゲート誤 り確率を 0.1 以下にするためには、ゲート幅を $80 \mathrm{~m}$ 以上にする必要があることが分かる。この様に、 ある誤り確率を仮定することでゲート幅の大きさ を求めることができ、解析を行う上での一つの基 準策定に応用できると考光る。

\section{2 推定針路及び推定速力}

評価指標として利用される針路や速力は、レー 多観測位置の変化から計算される。KGPS位置の 変化から計算される針路・速力と、レーダ観測位 置の変化から計算した針路・速力の差を、それぞ れ、針路誤差及び速力誤差として、それらの時間 変化を図 9 に示す。同図は横軸に時間（ 0 時 0 分 からの積算した「分」の数値)、右縦軸に針路誤差 を、左縦軸に速力誤差を取っている。この図から、 レーダによる針路及び速力の推定は、突発的に大 きな䛊差が生じる場合があることが分かり、針路 ・速力を評価指標とする場合には、十分な平均化 処理等を行う必要があることが分かる。

\section{3 方位誤差}

方位誤差は、2.3の(3)に示したレーダの位置検出 のアルゴリズムの概要から、映像のビーム方向の 広がり（観測位置からのアスペクト角と距離）と の相関が予想できたため、方位䛊差の絶対値と座

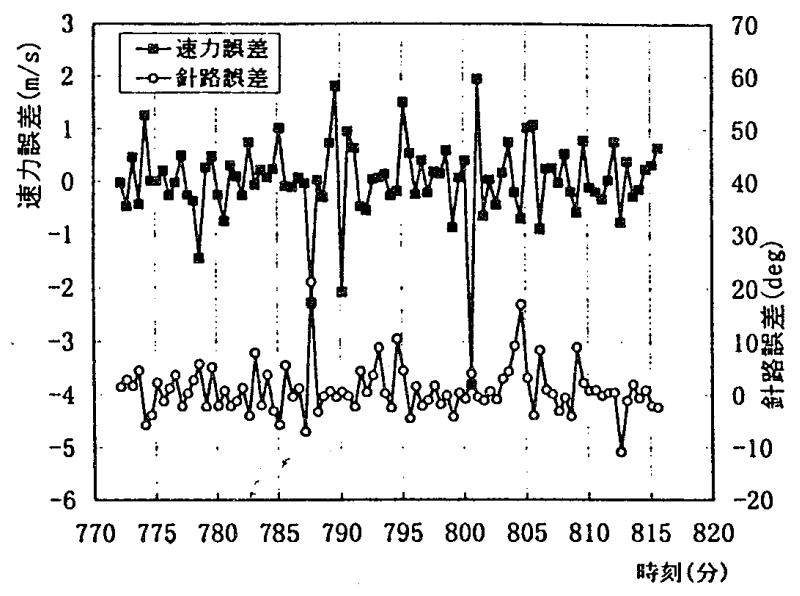

図 9 針路誤差及び速力誤差の時間変化の状沉

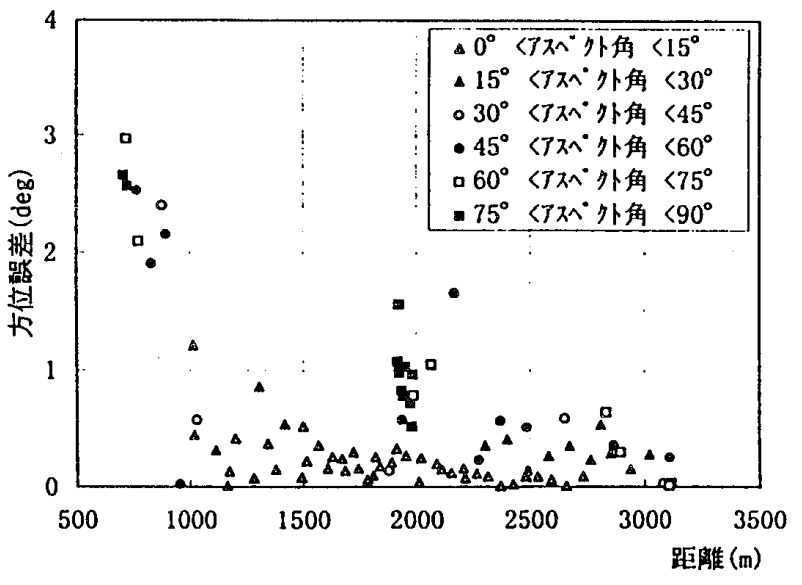

図10＼cjkstart方位誤差と距離及びアスペクト角の状況

標原点からの「こじま」のアスペクト角と距離についてまとめた。図10にその結果を示す。同図において

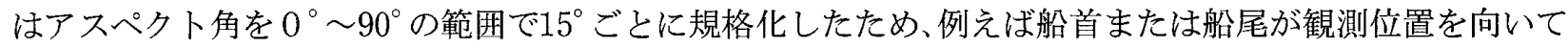
いる時が $0^{\circ}$ となっている。この図から、船首尾が観測位置方向を向いている時は近距離であっても方位誤 差は小さく、また、アスペクト角が $90^{\circ}$ 近くであっても、距離が遠ければ同様に方位誤差は小さいことが、 更に、これとは逆に近距離でアスペクト角が $90^{\circ}$ に近い程大きな方位誤差が発生する場合があることが分か る。すなわち、レ一ダの方位捠差の発生状況には、映像の幾何学的な大きさと相関があることが推察でき た。

\section{5. まとめ}

KGPS測位位置とレーダ観測位置を比較解析した結果を以下にまとめる。

(1) レーダ観測における船舶位置䛊差は、観測海域における航行船舶の進行方向によって、同一海域にお いても誤差量の発生状況に違いがあり、今回の測定から類推すると、船首尾方向に約 $\pm 1 / 4 L$ 、正横方向に 約 $\pm 1 / 2 B$ （ $L$ : 全長、 $B:$ 幅）の範囲でばらつく。

(2) レーダ観測におりる船舶位置誤差が海上交通の量的な評価指標に及ぼす影響等を考察した結果、

(1)海岸線等を平面座標に置き換えレーダ観測位置を同一座標で表現する場合など、座標を整合させる際 に固定誤差が大きく影響してくる可能性があるため、座標原点の位置精度について十分な注意が必要で ある。

(2)正横方向誤差の正規性からゲート通過誤り確率を仮定することで、解析に用いるゲート幅を決定する 
ことが可能となった。

(3)レーダ 観測位置の変化から推定する針路及び速力は大きな誤差が発生する場合があるため、十分な平 均化処理が必要である。

(3) レーダ 観測位置を極座標で表す場合

今回の観測海域程度の広さ及びレーダ信号処理方法によれば、距離誤差は、ほぼ正規分布することが、 また、方位誤差は、船首尾が観測地点を向いている時は小さく、船舶からの映像が良好に受信できる近距 離に掞いては大きな誤差が現れることがあることが分かった。

また、今回の解析には以下のような問題点も残るので、今後の検討課題としたい。

(1) 解析対象の船舶は当大学校の練習船「こじま」のみで、形状から見ても特殊な船舶であることから、 通常の貨物船等、一般的な船型においても更に検討する必要がある。

（2）情報管理室のレーダは、津島及び湊町の 2 個所に設置されており、レーダの設置位置から測定した方 位・距離によって、船舶位置を求めているのではないことから、レーダ反射信号強度との関係から測定誤 差を検討することができていない。

(3) レーダの方位䛊差は映像の大きさ（アスペクト角と距離）との相関が見られたが、データ数が十分で ない等の理由により、定量的評価が行えていない。等である。

最後に、今回の実験に際し、全般的な調整等ご尽力頂き、また、研究内容につき多大な示唆を賜った、 広島大学小瀬邦治教授、及び㥶験にご協力頂いた本州四国連絡橋公団、トリンブルジャパン社、練習船「こ じま」清水昭夫船長を始め乗組員等関係各位の方々に感謝致します。

\section{参 考 文 献}

（1）土屋 淳・辻 宏道著：「やさしいGPS湘量」，日本測量協会，pp.390～395，1991.

（2）日本測地学会編著：「GPS一人工衛星による精密測位システムー」，日本測量協会，pp.178，1989.

\section{質 疑 応 答}

和気博嗣（神戸商船大学）：今回「こじま」による実船結果の比較とこれを一般船舶における誤差を推定す る場合の特に変化する要因、見込みについてお教え下さい。

山田多津人：船舶からのレーダ反射信号強度は、その船型（船橋構造等）によって大きく変化すると思わ れますが、方位・距離を検出するアルゴリズムが今回のレーダ装置と同じ（一定なしきい值以上を示す 映像の平均的な方位と距離から位置を求める）であれば、䛊差の発生状況に大きな違いは起こらないの ではないかと考えます。しかし、ご指摘の点等更に検討すべきと考えておりますので、今後の検討課題 としたいと思います。 